\title{
MEMBANGUN KEAMANAN REGIONAL DI ASEAN DALAM MENANGGULANGI ANCAMAN TERORISME
}

\section{Arfin Sudirman, dan Deasy Silvya Sari}

\author{
Departemen Hubungan Internasional FISIP Universitas Padjadjaran \\ E-mail: arfinsudirman@gmail.com
}

\begin{abstract}
ABSTRAK
Ancaman terorisme yang marak berkembang, terutama pasca tragedi 9/11, membayangi stabilitas keamanan di Asia Tenggara. Terdapat gerakan-gerakan separatis di beberapa negara anggota ASEAN yang dikhawatirkan gerakan-gerakan ini melakukan tindakan radikal yang mampu menggoyahkan stabilitas keamanan regional. Masing-masing negara ASEAN telah berupaya untuk mengatasi gerakan tersebut. Sayangnya, terorisme merupakan kejahatan transnasional yang penanganannya sulit dilakukan oleh satu negara saja sehingga membutuhkan kerjasama regional dalam rangka membangun keamanan regional di kawasan Asia Tenggara. Tujuan artikel ini adalah untuk menelaah upaya-upaya membangun keamanan regional di bawah ASEAN dalam rangka menanggulangi ancaman terorisme di kawasan Asia Tenggara. Manfaat tulisan ini diarahkan bagi pengembangan kajian keamanan regional dalam Studi Hubungan Internasional dengan lokus Asia Tenggara. Artikel ini menggunakan pendekatan kualitatif. Objek kaji adalah regulasi ASEAN mengenai penanganan terorisme sebagai tatanan rezim regional keamanan di ASEAN. Teknik pengumpulan data wawancara untuk mendapatkan data primer yang menguatkan studi literatur untuk memperoleh data dalam mengkaji dokumendokumen regulasi keamanan di ASEAN. Proposisi artikel ini adalah ASEAN sebagai sebuah asosiasi kerjasama regional memliki peran signifikan dalam harmonisasi upaya kontra terorisme di kawasan Asia Tenggara. Penelitian ini menemukan bahwa ASEAN memiliki seperangkat kebijakan kontra terorisme yang telah diratifikasi dalam jangka waktu berbeda oleh para anggotanya sebagai bentuk harmonisasi kebijakan regional. Namun, dalam level strategis, negara-negara ASEAN memiliki otoritas sendiri untuk mengatasi isu terorisme dengan kemungkinan untuk menjalin sebuah kejasama dengan negara yang bukan anggota ASEAN. Sebagai tambahan, Amerika Serikat juga memiliki peran signifikan dalam membantu upaya kontraterorisme bagi negaranegara anggota ASEAN.
\end{abstract}

Kata Kunci: ASEAN, Kontraterorisme, Kerjasama Keamanan Regional, Harmonisasi

\section{BUILDING REGIONAL SECURITY IN ASEAN IN COUNTER TERRORISM EFFORT}

\begin{abstract}
The terrorism attack in the 9/11 tragedy has been overshadowing the security and stability in Southeast Asia. There are separatist movements in some ASEAN countries which potentially transformed into radical-violence group that could destabilize security and stability in the region. Each ASEAN countries have an obligation to overcome the movement. Unfortunately, terrorism is considered as a transnational crime that requires regional cooperation in order to establish regional security in Southeast Asia. The objective of this article is to examine efforts to build regional security under the ASEAN and the purpose of to analyze the harmonization of counter terrorism cooperation between ASEAN members in order to tackle the threat of terrorism in Southeast Asia. Based on primary and secondary data by using qualitative method the research found that ASEAN has a set of counter terrorism policies that had been ratified several times as a form of regional policies harmonization. However in terms of strategic-operational level, the ASEAN's member states has the authority to tackle terrorism issue on their own with the possibility to establish a cooperation with a non ASEAN member state. In addition, the US also has a significant role in assisting counter terrorism effort for ASEAN's states members.
\end{abstract}

Key words: ASEAN, Counter Terrorism, Regional Security Cooperation, Harmonization 


\section{PENDAHULUAN}

Setiap negara anggota ASEAN memiliki persepsi ancaman yang berbeda mengenai isu terorisme. Persepsi ini ada yang berkaitan dengan tragedi 9/11 ada juga yang tidak. Indonesia, misalnya, memandang gerakan-gerakan yang merongrong kemerdekaan dianggap sebagai isu terorisme karena pemerintah Indonesia harus menghadapi serangan gerilyawan yang memiliki jaringan gerakan yang tertata rapi. Pasca tragedi 9/11, Indonesia mengalami serangkaian bom yang disinyalir memiliki keterkaitan langsung dengan jaringan teroris global yang berada di Afghanistan.

Pesepsi ancaman teorisme di Vietnam lebih mengarah pada terorisme maritim serta gerakan separatisme di Thailand Selatan. Di Malaysia, jaringan kelompok Komunis pra 9/11 dan jamaah Islamiyah pasca 9/11 dipandang sebagai teroris yang merongrong keamanan nasional Malaysia terlebih dengan berlangsungnya peristiwa pembajakan pesawat Malaysia Airlines 653 (pada 1977) dan keterlibatan beberapa warga negara Malaysia yang menjadi pentolan aksi-aksi teror di Indonesia.

Tiga peristiwa pemboman yang berlangsung di Myanmar (Ranggon, 1983; Yangon, 2005 dan 2010) mempersepsi pemerintahan Myanmar akan eksistensi teroris di negaranya. Agen Korea Utara, united liberations Front of Assam dan United National Liberation Front disinyalir sebagai jaringan aktor-aktor teroris di Myanmar.

Meski tergolong aman, pemerintah Singapura tetap waspada dengan ancaman teroris. Terlebih, pada 1965, Singapura pernah mengalami pemboman di McDonald dan pembajakan pesawat Singapore Airlines pada 1991. Pasca tragedi 9/11, pemerintah Singapura aktif dalam serangkaian kerjasama dalam memberantas terorisme, khususnya dalam menghadap gerakan jaringan Jamaah Islamiyah dan Moro Islamic Liberation Front.

Filipina mengalami serangkaian serangan teroris, seperti pemberontakan Moro National Liberation Front (2001), pembunuhan wisatawan asing di Filipina Selatan (2001), serangan di Manila (2002), pengeboman pangkalan militer Filipina di Zamoanga (2002), pengeboman Bandara di Davao City (2003) serta penembakan kapal Ferry (2004). Aksi-aksi teror ini disinyalir dilakukan oleh new People's Army (NPA), Jamaah Islamiyah, Moro National Liberation Front (2001), Moro Islamic Liberation Fron (MILF) dan Abu Sayyaf Group (ASG).

Ancaman teroris bagi pemerintah Kamboja berasal dari sisa-sisa simpatisan Khmer Merah dan Cambodian Freedom Fighters $(\mathrm{CFF})$. Jaringan gerakan ini pernah melakukan pelemparan granat dan serangan terhadap instalasi pemerintahan Kamboja di Amerika Serikat pada 2000. Bagi Negara Brunei Darussalam, meski tidak terjadi seranganserangan teroris, namun negara ini sangat aktif melakukan kerjasama menyangkut isu terorisme. Sementara negara Laos dan Vietnam tergolong sebagai negara yang aman dari isu terorisme.

Guna menghadapi serangkaian isu terorisme, negara-negara anggota ASEAN telah melakukan berbagai upaya kontraterorisme yang didukung dengan eksistensi serangkaian kebijakan formal. Artikel ini bertujuan untuk menelaah upaya-upaya membangun keamanan regional di bawah ASEAN dalam rangka menanggulangi ancaman terorisme di kawasan Asia Teng-gara. Manfaat tulisan ini diarahkan bagi pengembangan kajian keamanan regional dalam Studi Hubungan Internasional dengan lokus Asia Tenggara.

\section{METODE}

Studi ini bertujuan untuk mengetahui memahami proses kerjasama yang ideal bagi organisasi regional dalam menanggulangi suatu ancaman regional yang bersifat transnasional melalui kacamata liberal institusionalisme. Metode penelitian yang digunakan dalam penelitian ini adalah metode kualitatif dengan menggunakan teknik library research, internet research dan wawancara terstruktur dari praktisi bidang keamanan dan pertahanan di ASEAN serta praktisi di bidang kerjasama regional di negara-negara anggota ASEAN. Penelitian ini pun menggunakan metode deduktif dimana untuk menganalisis tantangan dan peluang harmonisasi kerjasama ASEAN dalam memberantas tindak pidana terorisme digunakan teori Liberal Institusionalisme. Teori ini digunakan untuk menekankan pentingnya peran institusi internasional yang menjadi wadah kerja sama antar aktor negara meskipun dalam lingkungan sistem internasional yang 
anarki ${ }^{1}$.

Penggunaan metode penelitian kualitatif dalam penelitian ini adalah untuk mencari makna dari suatu fenomena yang akan diteliti untuk mencari pemahaman-pemahaman ilmiah. Fenomena terorisme yang terjadi di AS pada tanggal 11 September 2001 merupakan pertanda bahwa aksi terorisme tidak mengenal ruang dan waktu. Tidak ada yang dapat memprediksi kapan ancaman tersebut dapat datang di kawasan asia tenggara. Oleh karena itu ASEAN sebagai institusi regional diharapkan dapat menjadi peredam ancaman tersebut melalui harmonisasi kerjasama yang baik.

Pengolahan data dalam penelitian ini akan dilakukan melalui reduksi data jika data yang didapat selama berada di lapangan terlalu banyak dan tidak relevan dengan masalah penelitian. Kemudian analisis data akan dilakukan melalui triangulasi teknik terhadap hasil wawancara dengan hasil teknik studi literatur dan internet method melalui dokumentasi dan teori serta member check untuk melakukan verifikasi data. Selain itu penyajian data melalui penulisan secara kualitatif dan naratif serta penarikan kesimpulan berdasarkan temuan-temuan yang ada setelah seluruh kegiatan penelitian telah dilakukan.

Sumber data diperoleh dari pengumpulan data yang dilakukan dengan studi pustaka, berupa dokumen atau arsip yang di dapat dari pihak Direktorat Politik dan Keamanan ASEAN dan First Political Secretary masing-masing perwakilan negara anggota ASEAN yang berada di Jakarta termasuk Direktur Kerjasama Internasional dan Perlucutan Senjata di Kementerian Luar Negeri RI di Jakarta. Selain itu, Penulis juga menggunakan data sekunder yang diperoleh dari studi kepustakaan (library research) dan studi internet (internet research) dengan menggunakan berbagai informasi terkait upaya ASEAN dalam melakukan kerjasama kontra terorisme di kawasan Asia Tenggara dan kebijakan kontra terorisme masing-masing negara anggota ASEAN sebanyak-banyaknya yang berasal dari buku, jurnal, majalah, surat kabar, terbitan-terbitan khusus, situs resmi yang dimiliki oleh ASEAN, Lembaga Kajian ASEAN, Kemenlu serta referensi lainnya yang dianggap sesuai dengan penelitian ini.

\footnotetext{
Rebecca Devitt on September 1, 2011, Liberal Institutionalism: An Alternative IR Theory or Just Maintaining the Status Quo?, http://www.e-ir.info/?p=13482, diakses pada tanggal 5 Desember 2011
}

\section{HASIL DAN PEMBAHASAN}

\section{Regulasi Kontra Terorisme Negara-Negara Anggota ASEAN}

Pada 2002, lahir Instruksi Presiden No.5 tahun 2002 yang ditujukan kepada Kepala Badan Intelejen Negara (BIN) untuk penanganan terorisme di Indonesia. Kebijakan ini diperkuat dengan Undang-undang No. 15 tahun 2003 tentang Penetapan Peraturan Pemerintah Pengganti Undang-Undang Nomor 1 tahun 2001 tentang Pemberantasan Tindak Pidana Terorisme. Bekerjasama dengan pemerintah Amerika Serikat, Kejaksaan Agung Republik Indonesia mendirikan Terrorisme and Transnational Crime Task Force (TTCTF). Beberapa institusi resmi dibangun untuk kontraterorisme, seperti Detasemen C Gegana Brimob, Densus 88 (Polri), Desk Anti Terror, BNPT, TNI (Dengultor, AD, AU, Marinir AL) ditambah Babinsa, dan BIN.

Pemerintah Thailand memiliki Supreme Command of the Royal Thai Armed Forces yang bergerak pada tataran operasional kontraterorisme. Terdapat juga institusi lain, seperti Counter Terrorism Program oleh Royal Thai Navy, the National Security Council (NSC) yang dipelopori oleh Kementerian Luar Negeri Thailand, Thailand Maritime Enforcement Coordination Center (THAI-MECC), Marial Law against insurgency di daerah Thailand Selatan (Darurat militer dan jam malam di daerah Pattani, Yala dan Narathiwat tahun 2004) serta Perluasan penanganan kontra terorisme di sektor finansial, TNC dan Narkoba.

Dalampenanggulanganteroris, pemerintah Malaysia melibatkan semua level masyarakat termasuk militer, polisi, keamanan perbatasan, pertahanan sipil, medis dan persiapan psikologis. Pemerintah Malaysia memiliki serangkaian kebijakan berkaitan dengan terorisme, seperti Internal Security Act (ISA), Penal Code, dan Rejimen Gerak Khas di bawah pelatihan British 22nd SAS.

Pemerintah Myanmar meratifikasi ASEAN Convention on Counter Terrorism pada 2012 dan melegislasi kebijakan strategic anti-money laundering and countering the financing of terrorism (AML/CFT) deficiencies pada 2011. Sementara pada tataran hukum nasioanl, kebijakan atau undang-undang mengenai kontraterorisme masih sebatas pada Criminal Justice Sistem (Undang-undang subversif). 
Dalam menghadapi ancaman terorisme, Singapura memiliki seperangkat kebijakan, seperti Internal Security Act, Singapore Armed Forces Act, membentuk pasukan khusus Air Marshal Unit, Police MRT Unit, Singapore Special Operations Force, Special Operations Command, Chemical, Biological, Radiological and Explosive Defence Group, Undangundang anti-money laundering/counter terrorist financing regimes, melakukan pelatihan militer dengan China dan Amerika Serikat, serta melakukan deradikalisasi muslim klerik dengan pemberdayaan potensi-potensi umat muslim.

Beberapa kebijakan yang digulirkan pemerintah Filipina dalam menghadapi terorisme, di antaranya National Plan to Address Terrorism and its Consequences (2002), Autonomous Region of Muslim Mindanao (ARMM), Operation Freedom Eagle 2002 berupa pengerahan personil militer AS di Filipina Selatan, Sokongan dana $\$ 92$ juta untuk bantuan militer di Mindanao pada 2001, Unit anti terror campuran antara Armed Forces of Phillipines dan Phillipines National Police, serta pembentukan Special Force Regiment untuk menangani terorisme.

Pemerintah Kamboja melakukan kerjasama dengan PBB dengan mendukung Resolusi DK PBB no 1368 dan 1373 tentang perang terhadap terorisme internasional. Membentuk Royal Cambodian Army Forces (RCAF) yang bekerjasama dengan militer AS berupa sharing informasi dan intelijen, pengawasan transaksi keuangan, akses terhadap penggunaan pesawat AS. Membentuk Royal Cambodian Armed Forces' 911 yang terdiri dari para komandan Battalion. Pemerintah Kamboja meratifikasi 4 konvensi internasional untuk memerangi terorisme dan meresmikan pendirian Sekretariat Cambodian National Counter Terrorism Committee (NCTC).

Pemerintah Brunei Darussalam mengeluarkan serangkaian kebijakan terkait dengan terorisme, seperti: Financing Terrorist Acts, Prevention Supression of Terrorist Acts, National Security, Travel and Border Safety, Generating Awareness, Cooperation on Information Exchange, dan Biological Attack. Sementara pemerintahan Vietnam masih mengandalkan Amandemen Penal Code tahun 2009 guna memberantas terorisme serta penekanan pada criminal justice response untuk memerangi ancaman terorisme.
Beberapaperistiwateroryangberlangsung di negara-negara anggota ASEAN menunjukkan bahwa ASEAN menghadapi complex security sebagai tantangan untuk mencapai keamanan regional. Complex Security ini muncul dari pengalaman yang berbeda dengan kelompok teroris yang melahirkan pendekatan kontra terorisme yang berbeda pula.

Tantangan ini sebetulnya merupakan hal yang lumrah bagi organisasi-organisasi regional di dunia. Untuk membangun sebuah konsensus apalagi komunitas politik keamanan ASEAN bukanlah sejenis pakta pertahanan layaknya NATO, ASEAN harus mampu mengakomodir persepsi ancaman masing-masing negara anggotanya yang berbeda-beda khususnya dalam menghadapi terorisme.

Meskipun demikian, dalam kasus terorisme faktor security complex relatif tidak terlalu signifikan karena sejak proses pembuatan ASEAN Joint Declaration on Counter Terrorism tahun 2001 tidak ada suara resisten dari negaranegara anggota ASEAN. Bahkan ketika kehadiran AS sebagai overlay sangat terasa terutama pada saat AS membantu di tingkat operasi strategis seperti penyediaan logistic dan persenjataan Densus 88 dan Polri di Indonesia serta militer Singapura pun tidak ada nota protes yang disampaikan oleh salah satu negara anggota ASEAN. Sebagai institusi, ASEAN pun tidak pernah keberatan akan kehadiran kekuatan strategi AS untuk penanggulangan terorisme di Asia Tenggara.

Hal yang sama pun berlaku kepada masingmasing negara anggota ASEAN sebagai negara yang berdaulat. Kebijakan kontra terorisme di negara-negara ASEAN didasarkan kepada persepsi ancaman masing-masing negara terhadap ancaman terorisme di negaranya yang semakin meningkat. Hal ini terlihat dari tabel pemetaan kebijakan kontra terorisme negaranegara ASEAN di atas di mana dalam tataran operasional-strategis tidak ada pendekatan dan tindakan kontra terorisme yang seragam.

Bagi Malaysia dan Singapura misalnya kebijakan ISA dan penegakkan hukum yang tegas yang sudah ada sebelum peristiwa 9/11 masih menjadi ujung tombak pencegahan aksi terorisme. Bagi Indonesia yang pernah mengalami peristiwa terorisme terbesar sepanjang sejarah ASEAN yaitu Bom Bali 
tahun 2002, penindakan tindak kriminal terorisme masih mengandalkan seluruh security apparatus yang dimiliki oleh negara mulai dari Badan Intelijen, BNPT, TNI, Polisi dan Jaksa meskipun sifatnya masih reaktif. Tetapi keunikan upaya kontra terorisme di Indonesia adalah dibentuknya militarized police dengan bantuan AS seperti yang terlihat pada logistik dan kapabilitas Densus 88.

Sementara di Thailand dan Filipina, upaya kontra terorisme masih sangat mengandalkan peran intelijen dan Militer terutama angkatan darat dan laut. Hal ini dilakukan karena kelompok-kelompok teroris yang beroperasi di kedua negara tersebut merupakan kategori pemberontak atau kelompok separatis bersenjata yang mengancam kedaulatan nasional mereka sehinggaperlupendekatanmiliteristik. Sementara bagi beberapa negara anggota ASEAN lainnya seperti Vietnam, Brunei Darussalam, Kamboja dan Myanmar upaya kontra terorisme masih menggunakan pendekatan hukum dan kriminal serta pembekuan asset tersangka terorisme tanpa sama sekali melibatkan kekuatan militer. Perbedaan operasi dan strategi kontra terorisme bergantung juga dari tingkat kerawanan dan pengalaman negara-negara tersebut dengan aksi terorisme. Oleh karena itu, berbeda dengan tataran kebijakan, harmonisasi kontra terorisme negara-negara anggota ASEAN tidak terimplementasi pada tataran operasional dan strategi karena otoritas untuk penanganan terorisme dikembalikan lagi kepada masingmasing negara anggota sebagai eksekutor kebijakan.

Bagi ASEAN sendiri, ASEAN sama sekali tidak keberatan dengan kehadiran AS untuk membantu negara-negara anggotanya dalam kontra terorisme di wilayahnya. Hal ini dapat terlihat dari kontribusi AS sejak tahun 2001 hingga sekarang dalam penanganan terorisme di negaranegara anggota ASEAN terutama Indonesia, Filipina, dan Thailand terutama dari segi finansial, logistik, strategi dan operasional. Bahkan dalam ASEAN Declaration on Joint Action to Counter Terrorism yang disetujui oleh seluruh anggota ASEAN pada tahun 2001 disebutkan bahwa "Underlining the importance of strengthening regional and international cooperation in meeting the challenges confronting us". Ini artinya, terdapat peluang bagi aktor negara di luar kawasan yang hirau akan keamanan regional Asia
Tenggara untuk menjalin kerjasama. Deklarasi ini memungkinkan AS untuk membantu negaranegara anggota ASEAN sangatlah besar tetapi apakah kenyataannya akan semudah itu?

Sebagai negara yang sedang siaga akibat peristiwa 9/11, perluasan agenda AS dalam Global War on Terror khususnya di Asia Tenggara memiliki beberapa tantangan. Persepsi masyarakat di Asia Tenggara yang mayoritas anti barat terutama akibat serangan unilateralnya terhadap Afghanistan dan Irak akan menimbulkan opini public negative tidak hanya AS tetapi juga negara anggota ASEAN tersebut. Padahal AS sangat berkepentingan dalam Global War on Terror di Asia Tenggara yang disebut-sebut sebagai front kedua AlQaeda. Selain itu, perang melawan terorisme membutuhkan informasi intelijen yang sangat kuat. Hal ini sangat sulit dilakukan karena berbeda dengan AS, mayoritas agen-agen intelijen negara-negara anggota ASEAN di gunakan untuk melanggengkan kekuasaan pemimpinnya. Artinya kemampuan intelijen negara-negara anggota ASEAN belum sampai pada standar yang dibutuhkan oleh AS untuk penanggulangan terorisme di Asia Tenggara. ${ }^{2}$ Oleh karena itu, untuk strategi dan operasionalisasi kontra terorisme di ASEAN tampaknya peran AS masih hanya terbatas pada pemberian pelatihan dan kebutuhan finansial serta logistic persenjataan canggihnya terutama kepada polisi negara-negara anggota ASEAN.

\section{Strategi dan Operasionalisasi Kontra Terorisme oleh ASEAN}

Dalam kelanjutan ASEAN Join Declaration on Counter Terrorism, ASEAN telah membuat laporan mengenai ASEAN Effort to Counter Terrorism yang dipresentasikan di depan UN - Counter-Terrorism Committee. Dalam dokumen tersebut, ASEAN secara kolektif mempersepsikan kejahatan terorisme sebagai kejahatan luar biasa yang akan menghambat pencapaian ASEAN Vision 2020. Perlu diingat kembali bahwa dampak 9/11 terhadap ASEAN adalah peningkatan persepsi ancaman ASEAN terhadap terorisme yang mengeksklusifkan terorism dari kejahatan transnational organized crime. Untuk menanggulangi permasalahan terorisme di

${ }^{2}$ David Wright-Neville. US Counter-terrorism in Southeast Asia: Problems on the Horizon. Dalam Vicziany, M, Wright-Neville, D, Lentini, P. (2004). Regional Security in the Asia Pasific: 9/11 and After. Massachusetts: Edward Elgar Publishing, Inc. hal: 51-55. 
Asia Tenggara, maka beberapa langkah perlu dilakukan oleh ASEAN termasuk kerjasama dengan negara di luar ASEAN termasuk PBB.

Strategi dan operasionalisasi kontra terorisme di ASEAN sebetulnya sudah dilaksanakan di masing-masing negara. Setidaknya terdapat dua strategi kontra terorisme utama yang dilakukan oleh negara-negara anggota ASEAN dan hal ini merupakan kesepakatan bersama sebagai follow up dari ASEAN Declaration on Joint Action to Counter Terrorism:

\section{a. Kerjasama Intelijen melalui $A S E A N$ Chiefs of Police (ASEANOPOL)}

Strategi dan operasi ASEANAPOL khususnya di bidang terrorisme mencakup beberapa hal, yakni; pertukaran informasi yang berkaitan dengan tersangka terrorisme dan organisasi terkait terrorisme, berbagi informasi dan fasilitas akses diantara Negara anggota dalam menginterview tersangka teroris, menyediakan bantuan kepada Negara anggotta termasuk pelacakan, pembekuan, dan penyitaan assets yang terkait dengan teroris atau organisasi yang terkait teroris dan mempromsikan kerjasama yang erat antara entitas penegak hukum dan institusi keuangan ${ }^{3}$. Serta menjalin kerjasama dengan entitas yang terkait semisal Interpol serta pembentukan pasukan anti terorisme di masing-masing negara anggota ASEAN. ${ }^{4}$ Namun demikian, ASEANOPOL ini ternyata bukan bagian dari struktur organisasi ASEAN. Penggunaan nama ASEAN di sini adalah untuk menunjukkan cakupan kawasan yang menjadi ruang lingkup pekerjaan ASEANOPOL. ASEANOPOL ini hirau dengan keamanan regional di kawasan Asia Tenggara yang juga merupakan joint partnership dengan Pemerintah AS. Tidak hanya dalam urusan terorisme namun juga dalam urusan trans national organized crime (yang sebelumnya merupakan bagian dari kejahatan terorisme). Selain itu, operasionalisasi kontra terorisme oleh ASEANOPOL ini juga meliputi pembekuan asset dan perjanjian ekstradisi teroris.

\section{b.Pelatihan bersama kontra terorisme di ASEAN}

Pernah dilaksanakan sebagai tindak lanjut dari The ARF Inter-Sessional Meeting on Counter Terrorism and Transnational

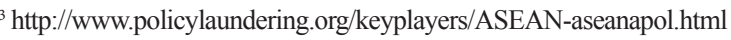
$4 \mathrm{http} / /$ www.interpol.int/News-and-media/News-media-releases/2011/ PR047
}

Crime (ISM CT-TC) yang disetujui di Sabah pada tahun 2003. Melalui konsensus ini, AS menyediakan dukungan teknis bagi beberapa negara ASEAN untuk melakukan pelatihan bersama seperti pasca ledakan, investigasi forensik, pelatihan pasukan respon cepat, keamanan perbatasan, pengembangan software, dan cyberterrorism. Selain itu, pelatihan pengamanan penerbangan dan lokakarya kesiapan menghadapi senjata kimia, biologi dan nuklir oleh kelompok teroris pun dilakukan antara AS dengan Singapura serta Australia.

Oleh karena itu, apa yang saat ini terjadi di Asia Tenggara sejak tahun 2001 sampai dengan sekarang dapat dikatakan selaras dengan kepentingan AS dalam konteks Global War on Terror. ASEAN menyediakan landasan kebijakannya tetapi dalam konteks operasional dan strategi kontraterorisme, semuanya diserahkan kepada masing-masing negara anggota ASEAN itu sendiri apakah dengan atau tanpa bantuan AS. Konsistensi ASEAN untuk tidak melakukan kontra terorisme di tataran operasional-strategi didasari atas landasan tujuan ASEAN Charter itu sendiri yaitu fokus pada confidence building measure, pendekatan damai terhadap segala ancaman dan sengketa tanpa perlu mendeklarasikan diri sebagai pakta pertahanan seperti NATO apalagi membentuk pasukan khusus ASEAN. Jika hal itu dilakukan tentu akan mengubah konstelasi perimbangan kekuatan di kawasan Asia, apalagi ancaman yang muncul adalah ancaman terorisme yang bersifat abstrak. Dengan demikian, keamanan regional di Asia Tenggara tampaknya sedikit banyak masih bergantung dari peran AS khususnya dalam upaya kontra terorisme.

\section{Harmonisasi ASEAN dalam upaya kontra terorisme di Asia Tenggara dalam konteks ASEAN Political and Security Community}

Sebagai organisasi kerjasama tingkat regional, pada prinsipnya ruang lingkup kerjasama ASEAN tidak tergantung pada dinamika internal di kawasan Asia Tenggara saja. Sebelum peristiwa 9/11 ASEAN memiliki persepsi sendiri terhadap ancaman terorisme. Signifikansi ancaman terorisme saat itu masih sebatas pada lingkup kejahatan lintas batas negara sama seperti kejahatan narkoba dan Human Trafficking. Hal ini terlihat jelas pada kesepakatan Second Informal Summit tahun 
1997 di Kuala Lumpur yang memasukkan ancaman terorisme sebagai bagian dari program pemberantasan transnational crime di kawasan Asia Tenggara. Namun tragedi 9/11 yang terjadi di AS memberikan persepsi ancaman baru bagi ASEAN terhadap aksi terorisme itu sendiri. Tidak hanya dari segi besarnya skala serangan serta dampak dari 9/11 secara global namun juga ASEAN mempersepsikan bahwa ancaman terorisme dapat menghambat tercapainya ASEAN Vision tahun 2020 sehingga butuh penanggulangan khusus.

Sebagai respons dari persepsi ancaman baru tersebut, salah satu kesepakatan kolektifyang juga menjadi pelopor-dalam kerjasama kontra terorisme ini adalah disepakatinya ASEAN Declaration on Joint Action to Counter Terrorism yang disepakati di Brunei Darussalam tahun 2001 yang meliputi kolaborasi, kerjasama dan koordinasi terutama pada tingkat Menteri seperti ASEAN Ministerial Meeting on Transnational Crime, ASEAN+3 dan ASEAN Regional Forum (ARF) dengan tetap memegang teguh pada prinsip-prinsip non intervensi dan pendekatan non kekerasan. Inti dari kesepakatan-kesepakatan ini adalah optimalisasi kerjasama keamanan regional terutama di 6 level strategis yaitu: pertukaran informasi (yang melibatkan intelijen dan polisi), kerjasama di bidang hukum, kerjasama di bidang penegakkan hukum, pembangunan kapasitas institusi yang diinterpretasi sebagai confidence building measure, pelatihan kontra terorisme bersama antar pasukan kontra terorisme yang dimiliki oleh masing-masing negara anggota ASEAN dan kerjasama ekstra regional.

Kesepakatan ini merupakan landasan politik awal dari kerjasama negara-negara anggota ASEAN dalam upaya kontra terorisme di kawasan Asia Tenggara. Diikuti dengan beberapa kesepakatan kerjasama kontra terorisme lainnya seperti ASEAN Plan of Action to Combat Transnational Crime tahun 2002, Joint Declaration of ASEAN and China on Cooperation in the Field of Non-Traditional Security Issues tahun 2002, ASEAN Convention on Counter Terrorism tahun 2004 dan titik kulminasinya diakomodir pada pembentukan ASEAN Political and Security Community sebagai salah satu pilar kerjasama the New ASEAN Charter pada tahun 2008.

Dalam proses pembuatannya, peran AS untuk mempengaruhi dihasilkannya kebijakan ini dapat dikatakan tidak terlalu signifikan.
Dalam proses pengambilan keputusannya, AS sama sekali tidak berusaha untuk menekan apalagi memaksaASEAN sebagai institusi untuk bertindak sesuai dengan kebijakan luarnegerinya dalam Global War on Terror sebagai respon terhadap peristiwa 9/11. Apa yang menyebabkan ekskalasi kontra terorisme di negara-negara anggota ASEAN pasca 9/11 adalah dampak dari peristiwa-peristiwa terorisme besar yang terjadi di kawasan Asia Tenggara sendiri. Pemerintah Thailand mempersepsikan ancaman terorisme dengan fokus pada permasalahan Thailand selatan, Singapura mempersepsikan ancaman terorisme dengan fokus pada permasalahan gerakan Jamaah Islamiyah yang militant, Malaysia mempersepsikan ancaman terorisme dengan fokus kepada permasalahan mobilisasi aktor-aktor Jamaah Islamiyah yang tumbuh di negerinya, Filipina mempersepsikan ancaman terorisme dengan hirauan utamanya adalah gerakan pemberontakan oleh Moro/ MILF di daerah Filipina selatan, dan Indonesia mempersepsikan ancaman terorisme sebagai ancaman signifikan bagi keamanan nasional sejak peristiwa Bom Bali I tahun 2002 ditambah dengan potensi ancaman terorisme oleh kelompok simpatisan ISIS di Indonesia. Dengan demikian, maka dapat dikatakan bahwa tujuan ASEAN dalam merumuskan kerjasama kontra terorisme untuk melindungi keamanan regional di kawasan Asia Tenggara adalah untuk mengakomodir persepsi ancaman negara-negara anggotanya yang mulai terganggu oleh aktivitas terorisme melalui kerangka kerjasama di bidang keamanan. Dalam hal ini, security apparatus seperti kepolisian dan militer masing-masing negara anggota memainkan peran kunci untuk menanggulangi masalah terorisme di ASEAN.

Dalam deklarasi ASEAN Joint Action on Counter Terrorism disebutkan bahwa terorisme menjadi sebuah kejahatan yang secara eksklusif terlepas dari skema ancaman regional yang lebih besar yaitu trans national crime. Deklarasi ini merupakan perubahan dari kesepakatan sebelumnya yang ditandatangani oleh Kepala Negara masing-masing negara anggota pada Second Informal Summit pada bulan Desember 1997 di Kuala Lumpur. Deklarasi ini kemudian ditindaklanjuti dengan didirikannya ASEAN Political-Security Community sebagai salah satu pilar kerjasama New ASEAN Charter pada tahun 2007.

Sebagai pilar kerjasama yang hirau akan masalah-masalah keamanan dan politik 
di kawasan Asia Tenggara, maka dapat dikatakan bahwa ASEAN Political-Security Community merupakan payung kerjasama utama negara-negara anggota ASEAN dalam kontra terorisme. Dengan cita-citanya untuk tidak membentuk pakta pertahanan dan lebih mengedepankan capacity building, ASEAN Political and Security Community seharusnya dapat berperan lebih dalam isu-isu kritis di kawasan seperti terorisme terutama pasca 9/11. Melalui skema tersebut setidaknya terdapat empat implementasi Rencana Aksi Komunitas Politik Keamanan ASEAN yang harus menjadi prioritas utama dalam upaya harmonisasi kontra terorisme di wilayah Asia Tenggara:

\section{a. Konvensi ASEAN tentang Pemberantasan Terorisme (ASEAN Convention on Counter Terrorism/ACCT)}

ACCT ditandatangani pada KTT ke12 ASEAN di Cebu, Filipina, Januari 2007. Konvensi ini memberikan dasar hukum yang kuat guna peningkatan kerjasama ASEAN di bidang pemberantasan terorisme. Selain memiliki karakter regional, ACCT bersifat komprehensif (meliputi aspek pencegahan, penindakan, dan program rehabilitasi) sehingga memiliki nilai tambah bila dibandingkan dengan konvensi sejenis.

Harmonisasi kerjasama pada ACCT ini terlihat dari kekompakan negara-negara anggota ASEAN dalam menyetujui netralitas pengdefinisian terorisme sebagai musuh bersama dan juga upaya kontra terorisme dengan tetap menyesuaikan pada prinsip penegakkan HAM, Hukum Internasional dan resolusi PBB serta tanpa melabeli komunitas tertentu sebagai kelompok teroris. Penyesuaian Hukum Internasional dan resolusi PBB pun bukan berarti ASEAN mengabaikan prinsip-prinsip yang tercantum dalam ASEAN Charter seperti non intervensi dan penghormatan kepada kedaulatan territorial negara-negara anggotanya. Wilayah kerjasama yang disetujui dalam ACCT ini terfokus pada peningkatan kerjasama preventif seperti pertukaran informasi, peningkatan pengawasan perbatasan (border control), pembekuan asset tersangka teroris, perjanjian ekstradisi dan program rehabilitasi serta diutamakan di dalam wilayah yuridiksinya masing-masing. Artinya dalam merumuskan ACCT, ASEAN berupaya agar segala kebijakan yang berlaku di wilayah Asia Tenggara mengenai kontra terorisme adalah bebas dari kepentingan-kepentingan di luar kawasan serta konsisten dengan prinsip-prinsip dasar ASEAN Charter.

\section{b. Forum Regional ASEAN(ASEANRegional Forum/ARF)}

ASEAN Regional Forum (ARF) diprakarsai oleh ASEAN pada tahun 1994, sebagai forum untuk saling tukar pandangan dan informasi bagi negara-negara Asia-Pasifik mengenai masalah-masalah politik dan keamanan, baik regional maupun internasional. Sasaran yang hendak dicapai melalui ARF adalah mendorong saling percaya (confidence building measures) melalui transparansi dan mencegah kemungkinan timbulnya ketegangan maupun konflik di kawasan Asia Pasifik.

Dalam forum kerjasama ARF ini, ASEAN yang terdiri dari berbagai macam negara-negara di kawasan Asia Tenggara bersatu dalam satu institusi dalam forum dialog keamanan di luar PBB, yang dihadiri kekuatan besar dunia antara lain: Amerika Serikat, China, Rusia, Uni Eropa dan Jepang. Forum ini tidak ditujukan untuk menyesuaikan dengan kepentingan dan selera aktor lain di luar kawasan mengenai bagaimana upaya kontra terorisme seharusnya diimplementasitetapilebihkepadamenunjukkan ASEAN sebagai satu kesatuan menjalin hubungan dengan lingkungan eksternal untuk menumbuhkan rasa saling percaya dan dialog serta berkonsultasi dalam isu-isu keamanan termasuk terorisme.

Harmonisasi negara-negara anggota ASEAN dalam upaya kontra terorisme terlihat dari kesepakatan-kesepakatan yang difa-silitasi melalui forum ARF Statement on Measures Against Terroris Financing di Brunei Darussalam tahun 2002. Dalam forum tersebut, disebutkan bahwa seluruh anggota ASEAN berkomitmen untuk bekerjasama melawan terorisme dengan tetap berkoordinasi dengan beberapa organisasi internasional lainnya seperti PBB, International Finansial Institutions (IFIs), The Finansial Action Task Force Money Laundering (FATF) dan Finansial Stability Forum (FSF). Harmonisasi ini terlihat dari bagaimana negara-negara anggota ASEAN menyesuaikan upaya kontra terorisme dengan terfokus pada pembekuan asset kelompok teroris terlebih dahulu. Selain itu, untuk mengontrol 
kebijakan ini, ARF bertemu setahun sekali untuk mengevaluasi perkembangan langkah-langkah kontra terorisme ke depan.

\section{c. Kerjasama di Bidang Pemberantasan Kejahatan Lintas Negara}

Kerjasama ASEAN dalam rangka memberantas kejahatan lintas negara (transnational crime) pertama kali diangkat pada pertemuan para Menteri Dalam Negeri ASEAN di Manila tahun 1997 yang mengeluarkan ASEAN Declaration on Transnational Crimes. Dalam deklarasi kerjasama tersebut disepakati beberapa perjanjian yang telah dihasilkan ASEAN terkait dengan pemberantasan kejahatan lintas negara yaitu:

a) ASEAN Plan of Action to Combat Transnational Crimes yang mencakup kerjasama pemberantasan terorisme, perdagangan obat terlarang, pencucian uang, penyelundupan dan perdagangan senjata ringan dan manusia, bajak laut, kejahatan internet dan kejahatan ekonomi internasional;

b) Treaty on Mutual Legal Assistance in Criminal Matters (MLAT) ditandatangani tahun 2006;

c) Agreement of Information Exchange and Establishment of Communication Procedures ditandatangani tahun 2002, merupakan perjanjian di tingkat sub regional guna penanganan kejahatan lintas batas melalui pertukaran informasi;

d) ASEAN Declaration on Joint Action to Counter Terrorism ditandatangani tahun 2001 dalam penanganan terorisme; dan

e) ASEAN Convention on Counter Terrorism (ACCT) ditandatangani tahun 2007 sebagai instrumenhukumdalampenangananterorisme. Konvensi ini telah diratifikasi oleh dua negara yaitu Thailand dan Singapura, sementara Indonesia dalam proses untuk meratifikasi Konvensi tersebut. Telah dilaksanakan dua Working Group untuk membahas ASEAN Comprehensive Plan of Action on Counter Terrorism guna pengimplementasian ACCT.

\section{Harmonisasi negara-negara anggota} ASEAN terkait upaya kontra terorisme di wilayah Asia Tenggara terlihat dari kesadaran kolektifakan bahaya terorisme sebagai salah satu kejahatan yang diakibatkan oleh permasalahan trans national crime seperti Human Trafficking, peredaran obat-obatan terlarang dan peredaran senjata-senjata api illegal. Namun demikian, patut diketahui bahwa terorisme menjadi kejahatan sendiri yang harus mendapat perhatian khusus dari negara-negara anggota ASEAN adalah pada tahun 2001 ASEAN Declaration on Counter Terrorism. Pemisahan ancaman terorisme menjadi kejahatan khusus terlepas dari kejahatan trans national crime ini pun merupakan konsensus dari negara-negara anggota ASEAN karena wilayah Asia Tenggara yang terdiri dari bermacam-macam agama dan etnis sangat rentan dengan ancaman terorisme.

\section{d. Kawasan Bebas Senjata Nuklir Di Asia Tenggara (South-East Asia Nuclear Weapon Free Zone/SEANWFZ)}

South-East Asia Nuclear Weapon Free Zone (SEANWFZ) Treaty ditandatangani di Bangkok pada tanggal 15 Desember 1995 dan telah diratifikasi oleh seluruh negara ASEAN. Traktat ini mulai berlaku pada tanggal 27 Maret 1997. Pembentukan SEANWFZ menunjukkan upaya negara-negara di Asia Tenggara untuk meningkatkan perdamaian dan stabilitas kawasan baik regional maupun global, dan dalam rangka turut serta mendukung upaya tercapainya suatu pelucutan dan pelarangan senjata nuklir secara umum dan menyeluruh.

Traktat SEANWFZ ini disertai protokol yang merupakan suatu legal instrument mengenai komitmen negara ASEAN dalam upayanya memperoleh jaminan dari negara yang memiliki senjata nuklir (Nuclear Weapon State/NWS) bahwa mereka akan menghormati Traktat SEANFWZ dan tidak akan menyerang negara-negara di kawasan Asia Tenggara. Saat ini, negara-negara ASEAN dan NWS masih mengupayakan finalisasi formulasi beberapa masalah yang diatur dalam Protokol dimaksud. Penandatanganan Traktat SEANWFZ merupakan tonggak sejarah yang sangat penting bagi ASEAN dalam upaya mewujudkan kawasan Asia Tenggara yang aman dan stabil, serta bagi usaha mewujudkan perdamaian dunia.

Rencana aksi tersebut menetapkan langkah-langkah yang harus dilakukan oleh Negara Pihak dalam jangka waktu 20072012 sebagai berikut: (1) Compliance with the Undertakings in the SEANWFZ Treaty, (2) Accession by Nuclear Weapons States, (3) Cooperation with the IAEA; (4) Institutional Arrangements. 
Kesepakatan SEANWFZ merupakan harmonisasi yang memiliki nilai strategis penting bagi ASEAN dalam penanggulangan terorisme. Di tengah-tengah kekhawatiran negara-negara Barat akan kemungkinan akses teknologi senjata nuklir oleh kelompok teroris. Harmonisasi negara-negara anggota ASEAN dalam kesepakatan SEANWFZ terlihat dari komitmen negara-negara anggota ASEAN untuk tidak memproduksi dan mengembangkan senjata nuklir di wilayah Asia Tenggara. Sehingga kemungkinan upaya kelompok teroris untuk mendapatkan teknologi senjata nuklir menjadi berkurang. Bom Bali pertama tahun 2002 dapat dikatakan merupakan bom terbesar yang pernah diledakkan oleh kelompok teroris di kawasan ASEAN, namun dilihat dari bahan-bahannya yang terdiri dari racikan 1 $\mathrm{kg}$ TNT dan $50 \mathrm{~kg}$ RDX tidak ada sedikit pun yang mendekati elemen senjata nuklir seperti uranium atau plutonium. Bahan-bahan ini umumnya digunakan untuk keperluan industri pertambangan tetapi bukan untuk kebutuhan militer. Yang mungkin perlu diwaspadai adalah pengawasan terhadap penggunaan dan sirkulasi bahan-bahan berbahaya ini.

\section{SIMPULAN}

Sebagai sebuah kawasan yang mempunyai nilai penting dalam percaturan politik global, perkembangan isu terorisme di Asia Tenggara menjadi hal yang penting untuk ditelaah terlebih pasca tragedi 9/11. Dengan digulirkannya War on Terror oleh Amerika Serikat serta munculnya peristiwa-peristiwa terror di beberapa negara ASEAN, ASEAN merespon perkembangan isu-isu terorisme di kawasan ini dengan mengeluarkan serangkaian kebijakan terkait penanganan terorisme. Proses ratifikasi terhadap kebijakan-kebijakan yang ada menunjukkan harmonisasi dalam tataran kesepakatan di antara anggota ASEAN. Adapun dalam tataran praktis, ASEAN mempersilakan setiap anggota untuk mengembangkan upaya kontraterorisme dengan tidak menutup kemungkinan untuk mengembangkan kerjasama baik dengan sesa-ma negara anggota ASEAN maupun dengan negaranegara diluar kawasan Asia Tenggara. Amerika Serikat memiliki peran intrusif dalam proses penanganan terorisme di kawasan Asia Tenggara melalui pengembangan kerjasama bilateral dengan beberapa negara anggota ASEAN.

\section{DAFTAR PUSTAKA}

Adler, Emanuel and Barnett. eds. (1998). Security Communities. Cambridge: Cambridge University Press.

Audrey Kurth Cronin and Ludes. eds. (2004). Attacking Terrorism: Elements of a Grand Strategy. Washington, DC: Georgetown University Press.

Buzan, B., Waever, O., Wilde, J.D. (1998). Security: A New Framework of Analysis. London: Lynne Rienner Publisher.

Buzan, Barry. (1991). People, States and Fear: an Agenda for International Security Studies in The Post-Cold War Era. Boulder, Colorado: Lynne Rienner Publisher.

Lubis, Fuad Hasan. (2009). ASEAN Community 2015 dan Keamanan Regional: Studi Kasus Upaya ASEAN dalam Menangani Terorisme di Asia Tenggara. Disertasi, FISIP, Universitas Sumaterta Utara.

Pillar, Paul R. (2003). Terrorism and US Foreign Policy. Washington DC: Brookings Institution Press.

PaulF. Dhiel and Joseph Lepgold. Eds. (2003). Regional Conflict Management. New York: Rowman and Littlefield.

Suparman, Nuraeni; Sari, Deasy Silvya, dan Sudirman, Arfin. (2010). Regionalisme dalam Studi Hubungan Internasional. Yogyakarta: Pustaka Pelajar.

Wardlaw, Grant. (1982). Political Terrorism: Theory, Tactics and Counter-measures. Cambridge: Cambridge University Press.

Williams, Paul D. (2008), Security Studies: An Introduction .New York: Routledge.

Chalk, P. Rabasa, A. Rosenau, W. Piggott, L. 2009. The Evolving Terrorist Threat to Southeast Asia: A Net Assessment. Pittsburgh: RAND Corporation.

Wright-Neville, D. (2004). US Counterterrorism in SOutheast Asia: Problems on the Horizon. In M. Vicziany, \& D. L. P, Regional Security in the Asia Pacific: 9/11 and After (pp. 51-55). Massachussets: Edward Elgar Publishing.

ASEAN Selayang Pandang, diakses pada tanggal 5 Desember 2011 melalui www.deplu.go.id 
Rebecca Devitt on September 1,2011, Liberal Institutionalism: An Alternative IR Theory or Just Maintaining the Status Quo?, http://www.e-ir.info/?p=13482, diakses pada tanggal 5 Desember 2011
Sukma, Rizal. (2003). Keamaan Internasional Pasca 11 September: Terorisme, Hegemoni AS, dan Implikasi Regional dalam proceeding Seminar Pembangunan Hukum Nasional VIII oleh Badan Pembinaan Hukum Nasional, Departemen Kehakiman dan Hak Asasi Manusia RI. Denpasar, 14-18 Juli 2003.. 